\title{
Seedbed of Professionalism in Southeastern College Libraries, 1890-1920
}

$\mathrm{T}$ The seedbed of college libraries in the Southeast, as in much of the rest of the United States, lies in the Gilded and Progressive Ages of the 1890s to 1920. A great expansion of book production, literacy, and educational opportunities during the nineteenth century set the stage for this increase in libraries and professionalism. The template of library growth and transformation into information and research centers with trained librarians was established during these years, not earlier. ${ }^{1}$

The Southeast as a region provides a wide but coherent geographic area to investigate themes such as the growth of libraries and the introduction of library services. This was not a simple time of pastoral ease but an era of commercialization and even industrialization, a deepening and institutionalization of the Jim Crow racial code, of disfranchisement, of rigid sexism, and a heritage of violence in the Southeast. ${ }^{2}$ Yet it was also a time of ambiguity about the future allied with a quickening hope in education and library philanthropy. Some consider the centennial year 1876 as the Miracle Year of American libraries, yet it only marked a starting line for college libraries throughout much of the United States. ${ }^{3}$ The South itself scarcely participated in the first national conference that year while official founding dates for colleges rarely represent the establishment of vigorous library institutions. ${ }^{4}$ Even leading Ivy League institutions only began deliberately developing larger collections in the 1870s. ${ }^{5}$

It was during the two or three decades after 1890 that college libraries in the South began to build and catalog their collections, institute regular reference and research

\section{There was much left to do, but the seeds of southern libraries were beginning to sprout during the early years of the twentieth century. 9}

began to develop from insignificant academic institutions to hubs of the campus, from dated collections to engagement, within the context of a growing national print culture and an expanding college and university scene during the Progressive Era. Only by 1900 or so was there a regular, if still low, funding set aside services, employ full-time librarians, insist on some formal library training, and start meeting together in professional associations. Daniel Coit Gilman, the first president of John Hopkins in Baltimore and himself for many years the librarian at Yale, had opened the 1890s by speaking of the need for reference services within the quiet majesty of the library, a message that soon echoed throughout the South. ${ }^{6}$ Collection size, subject specialization, bibliographic expertise and circulation were also all becoming increasingly important to southern librarians.

The slow growth of library services during this period is representative of what was going on in American colleges, not unusual and not unique to the South, and so a study of the Southeast is pertinent to wider library history. College libraries only for the library even at the larger state universities in the South.

College libraries were shaped not only by their parent institutions and the communities they were part of, but by what was happening at other libraries. Librarians read about new developments in the emerging professional literature and discussed them with colleagues at meetings. The contemporary founding of state and regional library associations was especially important in the South because of distances involved and the general poverty that marked the area. Georgia formed the first southern state library association in 1897. By 1920 all the southern states had library associations, at which time an informal regional conference was held and then in 1922 the Southeastern Library Association formally began. ${ }^{8}$ 
Library associations were signs of an increasingly self-conscious interaction and professionalism. Verbal and social interchange complemented local insights and information gained from print sources. National travel took time and money, while most libraries had a very limited number of staff members to substitute, all of which lends greater weight to the librarians' professional determination to be more than part-time casual help. ${ }^{9}$

Much of the South was shifting from an agricultural to a commercial and even, in some areas, industrial society. Printed knowledge was increasingly important in the dissemination of practical knowledge. The South had hardly attempted to catch up culturally with the rest of the country until the 1890 s, but then it became increasingly a priority among the new generation of leadership. There were no ground rules for what constituted a real university at the time, but everyone agreed that a substantial and energetic library was a basic necessity. ${ }^{10}$

Typical of the situation throughout the South is what happened in North Carolina, which before the late 1890 s had only four or five college libraries of anything more than a few bookcases. None had a fulltime librarian, only at best a faculty supervisor or "curator." All had extremely limited operating hours. None were adequately cataloged and most did not even have an adequate list of titles. There were no card catalogs to encourage access, or little need for them as few new books were ever added. College libraries might have been "founded" in the eighteenth and nineteenth centuries but hardly became energetic and compelling institutions until the dawn of the twentieth, at which time a number of libraries moved into their own buildings and thereby justified an increase in their stock of books and magazines. ${ }^{11}$ Keeping up with rival colleges was always a prime motive in library expansion.

Prior to this period, not librarians but faculty chose most of the new books. The librarian was often a student under the supervision of a faculty member. At the University of South Carolina the situation became so dire that the president of the University himself officially assumed the librarian's duties around the turn of the century, with untrained female clerks doing most of the actual work. Even in a border state like Kentucky, as its president admitted in 1917, the University was still "lacking financial stability, clear academic organization, an adequate physical plant ... and sufficient faculty resources." 12 Before 1900 only about one-third of major colleges nationwide had a full-time librarian but this percentage soon rapidly increased - another sign of the historical importance of this period in library history.

During the 1890s and 1900s many universities and colleges began acquiring more books and therefore gave serious attention towards providing a card catalog. Cataloging was first undertaken by off-duty professors or students, but by the turn of the century it was not unusual for trained women catalogers to go from college to college cataloging and classifying collections. ${ }^{13}$ Librarianship was promising to become a career path for young college graduates.

At about the same time, reference services were initiated. For instance, Benjamin Wyche, who himself had taken only a little professional preparation at Amherst early in the 1890s, started offering reference services as first the librarian at the University of North Carolina and then at Texas. Speaking of library education, even
Louis Round Wilson who followed Wyche at North Carolina and later became dean of the nation's premier library school at the University of Chicago, only had two summer classes at Columbia University. The paucity of trained staff is indicated by Wilson only having one assistant until 1915, Jennie E. Lauderdale facing a similar situation at the University of Nashville in Tennessee. ${ }^{14}$

Many of the colleges in the South were private and Christian in orientation but poor in resources and funds. Not until 1908, for example, did Wake Forest hire a "regular" librarian instead of using a faculty member as curator. Southern public and private education was weak in bringing high schools and colleges and their libraries up to academic respectability. ${ }^{15}$

Money as well as space was a constant problem for college libraries once book collections and the number of students began to increase after the turn of the century. News of Carnegie philanthropy spread with the new century, however, and spurred colleges into applying for grants. New library buildings in turn often enticed increased donations of books although the Carnegie Corporation soon ceased making such grants in $1917 .{ }^{16}$

How much influence college librarians had over these grants is not clear as their presidents rarely brooked much input or interference from librarians during this period. A northern president once said his librarian's initials P. L. W. stood for "Placating Library Women." 17 Leaving aside the head librarian, at this time perhaps no one was more important in the life of a college library than its president who considered libraries the hubs of their schools. On the other hand, as yearbooks and 
memoirs show, women librarians were often remembered by their colleagues and students with fondness, their eccentricities no doubt growing with each telling at reunions. ${ }^{18}$

The librarians themselves were hardly members of the upper classes albeit as college graduates they were far better educated than the average person. Most were southerners although cataloging specialists might be from elsewhere. Almost all traveled north to gain their credentials. Their marital status varied. Male and female college librarians alike were expected to be reasonably diligent and accomplished at their tasks without being given much opportunity for career advancement outside of librarianship. Many were devoted to their jobs. Given the harsh segregation of the times, they also had to be observant of regional social rules.

Salaries were never substantial, although men might be paid twice as much as women. Low salaries were a major reason women were employed as librarians, even in otherwise all-male schools. Vanderbilt, for example, only became coed in 1896. Women were not generally admitted to the state universities or to the many male colleges but had separate female colleges, only a few of which were rigorous and ambitious enough to have substantial libraries. Of 142 southern female colleges that reported to one survey in 1912, only four were considered nationally accredited (Goucher, Agnes Scott, Randolph-Macon, and Newcomb). ${ }^{19}$ Meanwhile, money to improve libraries and librarians remained sparse. The woman librarians themselves seem to have had more training than their male counterparts, often going north to places like Drexel for education beyond college itself. Many apparently never married but few of them wrote much and certainly not about their personal lives. Much of the library school curriculum was more suited to public librarians than academic.

While women were largely excluded from the major colleges, they probably could use the libraries informally. Not so Black Americans. Higher education for African Americans hardly existed despite a number of small colleges scattered across the South and the nation. ${ }^{20}$ Racial tensions were high at the turn of the century. Segregation became increasingly codified in law and practiced in education and everyday life. The South, nonetheless, had African American higher educational institutions, many of them church supported. Most Black colleges mixed manual training and general education, but they hardly had the resources for extensive library collections. Some amounted to little more than a room at the turn of the century, while library education for Blacks did not begin until the 1920s and was devoted more to school librarianship. Many stalwarts, as in the white colleges too, were largely self-taught in librarianship. $^{21}$

By and large, northern philanthropists deferred to southern segregationist opinion and options at this time. ${ }^{22}$ Black academic libraries in the South had little opportunity to grow and develop in this atmosphere. Any increase in collection size, for instance, might be viewed with suspicion and even open hostility by the majority of whites as a turn towards unnecessary and harmful classical education. Raising matching funds for grants was therefore difficult. Fisk University however was successful and opened a new and stately library in 1909 - although a librarian later admitted that "You will find roomers in the library building. I have insisted upon, and have gotten in the main, silence during the library hours. They will [sic] cook however and toast and bacon aromas will waft down and permeate the whole building at all the hours of the morning." 23 Fire was indeed a prevalent danger in buildings used for administration, classes and dorms as illustrated by what happened at such institutions as Edward Waters College and Florida Baptist Academy. ${ }^{24}$

One national inspector, coming near the end of our period in 1917 , although perhaps biased, reported that Black college "libraries were usually a collection of old uninteresting books ... just a collection sent down by some one [sic] wishing to get rid of them, but thinking them too good to burn up." 25 Unfortunately, there is little reason to doubt his report, and indeed little has been written about African American academic libraries.

To sum up, the period from 1890 to 1920 saw the true birth of college and university libraries in the South and reflected a growing national concern for library service. Professionalism, improved catalogs, larger and better-selected collections, increased attention to the needs of faculty and students were all becoming major issues. Libraries were moving from being mere rooms to separate buildings with dedicated staff. Regular full-time employment of a limited number of trained librarians was beginning to be the norm by 1910 , at least in white colleges. While racism and sexism would hamper libraries in the South for many decades, librarians were striving to meet contemporary professional library obligations. Not just their collections but their personalities were having an impact on campus.

There was much left to do, but the seeds of southern libraries were beginning to sprout during the early years of the twentieth century. 


\section{References}

${ }^{1}$ Patrick M. Valentine, "The Origins of College Libraries in North Carolina: A Social History, 1890-1920," Information \& Culture: A Journal of History 47 (2012): 79-112; James V. Carmichael Jr., "Southerners in the North and Northerners in the South: The Impact of the Library School of the University of Illinois on Southern Librarianship," in Women's Work: Vision and Change in Librarianship (Carbondale: University of Illinois Graduate School of Library and Information Science Occasional Paper 196, 1994), 27-104; and Orvin Lee Shiflett, Origins of American Academic Librarianship (Norwood, NJ: Ablex Publishing, 1981).

2 Edward L. Ayers, The Promise of the New South: Life after Reconstruction (New York: Oxford University Press, 1992); and George Brown Tindall, Emergence of the New South, 1913-1945

(Baton Rouge: Louisiana State University Press, 1967).

3 Edward G. Holley, Raking the Historic Coals; the A.L.A. Scrapbook of 1876 (Chicago: Lakeside Press, 1967); and Kenneth E. Carpenter "Libraries," in A History of the Book in America, vol. 3: The Industrial Book 1840-1880, ed. Scott E. Casper, et al. (Chapel Hill: University of North Carolina Press, 2007), 303-318.

4 Patrick M. Valentine, "Small Select Library or Miserable Excuse: Antebellum College Libraries in the American Southeast," Southeastern Librarian 54 (2006): 6-11; and Haynes McMullen, American Libraries before 1876 (Westport, Ct: Greenwood Press, 2000).
5 Thomas F. O'Connor, "Collection Development in the Yale University Library, 1865-1931," Journal of Library History 22 (1987):170-171; Kenneth E. Carpenter, The First 350 Years of the Harvard University Library (Cambridge: Harvard University Press, 1986); James H. Canfield, in A History of Columbia University, 1754-1904 (New York: Columbia University Press, 1904), 437-41.

6 "University Libraries, an Address at the Opening of the Sage Library of Cornell University, Ithaca, October 7, 1891," in Daniel Coit Gilman, University Problems in the United States (New York: Century, 1898), 237, 250-55; and Louis R. Wilson, "The Growth of the Libraries ...” World's Work 14 (May-October 1907): 8985.

7 H. E. Shepherd, "Higher Education in the South," Sewanee Review 1 (1893): 283-89; Walter B. Briggs, "Reference Work in Public and College Libraries: A Comparison and a Contrast," Library Journal 32 (1907): 492495; and William Warner Bishop, "Training in the Use of Books," Sewanee Review 20 (1912): 265281. Benjamin Edward Powell, "The Development of Libraries in Southern State Universities to 1920" (Unpublished Ph.D., University of Chicago, 1946), Appendix III, provides comparisons of individual libraries.

8 Mary Edna Anders, "The Southeastern Library Association-1920-1950," Southeastern Librarian (1956) 9-80. The process was not without tensions and personal squabbles best recorded in Louis Round Wilson papers, Southern Historical Collection 3274, folders 105 and 106, University of North Carolina Wilson Library.
9 James V. Carmichael Jr., "Southern Librarianship and the Culture of Resentment," Libraries \& Culture 40 (2005): 324-352.

${ }^{10}$ John R. Thelin, A History of American Higher Education (Baltimore: John Hopkins University Press, 2004), 112, 127-31. Both Roger L. Geiger, To Advance Knowledge: The Growth of American Research Universities, 1900-1940 (New York: Oxford University Press, 1986); and Arthur M. Cohen, The Shaping of American Higher Education: Emergence and Growth of the Contemporary System (San Francisco: Jossey-Bass, 1998), largely ignore the role of libraries.

11 Wayne A. Wiegand, "Research Libraries, the Ideology of Reading, and Scholarly Communication, 1876-1900," in Libraries and Scholarly Communication in the United States: The Historical Dimension, ed. John Y. Cole (New York: Greenwood, 1990), 71-87.

12 Daniel Walker Hollis, History of the University of South Carolina (Columbia: University of South Carolina Press, 1956); Eric A. Moyen, Frank L. McVey and the University of Kentucky: A Progressive President and the Modernization of a Southern University (Lexington: University Press of Kentucky, 2011), 60.

${ }^{13}$ Valentine, "The Origins of College Libraries in North Carolina," 86; and Joanne Passet Bailey, "The rule rather than the exception': Midwest Women as Academic Librarians, 1875-1900," Journal of Library History, Philosophy \& Comparative Librarianship, 21 (1986): 476

${ }^{14}$ Wilson papers, 3274; "Garnet and Blue" (Yearbook), University of Nashville, 1902, list of faculty. 
15 George Brown Tindall, Emergence of the New South, 1913-1945 (Baton Rouge: Louisiana State University Press, 1967), 263267. For background see Patrick M. Valentine, "School Libraries in 19th Century North Carolina, 1800-1876: 'The Want of Books is Now an Immediate, Practical and Pressing One'," North Carolina Libraries 68/1 (Spring-Summer 2010), 6-10.

16 Neil A. Radford, The Carnegie Corporation and the Development of American College Libraries, 1928-1941 (Chicago: American Library Association, 1984). See also Patrick M. Valentine, "Steel, Cotton, and Tobacco: Philanthropy and Public Libraries in North Carolina, 1900-1940," Libraries \& Philanthropy, ed. Donald G. Davis, Jr. (University of Texas Press, 1996), 272-298.

17 Quotation, Winton U. Solberg, "Edmund Janes James Builds a Library: The University of Illinois Library, 1904-1920," Libraries \&
Culture 39 (2004): 52. Most of the surviving correspondence is by college presidents, not librarians. Carnegie Corporation of New York Records (microfilm reel 37).

18 Valentine, "Origins of College Libraries in North Carolina;" and James V. Carmichael Jr., "Women in Southern Library Education, 1905-1945," Library Quarterly 62 (1992): 169-216.

19 Elizabeth Avery Colton, "Standards of Southern Colleges for Women," School Review 20 (September 1912): 472.

${ }^{20}$ James D. Anderson, Education of Blacks in the South, 18601935 (Chapel Hill: University of North Carolina Press, 1988); and William A. Link, The Paradox of Southern Progressivism, 1880-1930 (Chapel Hill: University of North Carolina Press, 1992).

${ }^{21}$ Valentine, "Origin of College Libraries," 96-99.

22 Roy E. Finkenbine, "Law, Reconstruction, and African American Education in the
Post-Emancipation South," Charity, Philanthropy, and Civility, ed. Lawrence Friedman (New York: Cambridge University Press, 2003), 161-178, esp. 166-168.

${ }^{23}$ Jessica Carney Smith, "From Andrew Carnegie to John Hope Franklin: Library Development at Fisk University," Tennessee Libraries (Online) 59:4 (2009).

${ }^{24}$ Ana Guthrie, Frances Ba, Frances and Cheryl Wilcher, Cheryl, "The History of Florida's Four HBCU (Historically Black Colleges \& Universities) Libraries." Florida Libraries 55 (2012): 38-42.

25 United States, Office of Education, Negro Education; A Study of the Private and Higher Schools for Colored People in the United States (1917; rept. New York: Negro Universities Press, 1969), 1:47.

\section{North Carolina Libraries}

Official Publication of the North Carolina Library Association

ISSN 0029-2540

The subscription cost to North Carolina Libraries is $\$ 50 / y r$.

All issues are available online free-of-charge at http://www.ncl.ecu.edu.

Back issues are available from the North Carolina Library Association office at 1811 Capital Blvd., Raleigh, NC 27604 , for $\$ 8$ an issue for those years prior to going online in 2002 , or $\$ 50$ for the annual print compilation beginning with Vol. 60 (2002). 